Improved characterization of Clematis based on new chloroplast microsatellite markers and nuclear ITS sequences

\title{
Liu, Zhigao
}

2018-12

Liu , Z \& Korpelainen , H 2018 , ' Improved characterization of Clematis based on new chloroplast microsatellite markers and nuclear ITS sequences ' , Horticulture environment and biotechnology , vol. 59 , no. 6 , pp. 889-897 . https://doi.org/10.1007/s13580-018-0090-3

http://hdl.handle.net/10138/307841

https://doi.org/10.1007/s13580-018-0090-3

acceptedVersion

Downloaded from Helda, University of Helsinki institutional repository.

This is an electronic reprint of the original article.

This reprint may differ from the original in pagination and typographic detail.

Please cite the original version. 
2 Improved Characterization of Clematis Based on New Chloroplast Microsatellite Markers and Nuclear ITS Sequences 311300, China FI-00014 University of Helsinki, Finland

$14 *$ Corresponding author: helena.korpelainen@helsinki.fi 
Abstract. Currently, there is a lack of genetic markers capable of effectively detecting polymorphisms in Clematis. Therefore, we developed new markers to investigate inter- and intraspecific diversity in Clematis. Based on the complete chloroplast genome of Clematis terniflora, simple sequence repeats were explored and primer pairs were designed for all ten adequate repeat regions (cpSSRs), which were tested in 43 individuals of 11 Clematis species. In addition, the nuclear ITS region was sequenced in 11 Clematis species. Seven cpSSR loci were found to be polymorphic in the genus and serve as markers that can distinguish different species and be used in different genetic analyses, including cultivar identification to assist the breeding of new ornamental cultivars. Additional key words: genetic markers; genetic variation; molecular identification; ornamental plants, genetic relationships 


\section{Introduction}

Simple sequence repeats (SSR) or microsatellites are widely distributed throughout nuclear and cytoplasmic genomes in eukaryotes (Litt and Luty, 1989).

Because of their highly polymorphic nature, codominant inheritance, ubiquitous abundance and rapid mutation rates, SSRs have become useful markers for genetic diversity and population genetic analyses (Morgante et al., 2002; Selkoe and Toonen, 2006). Furthermore, SSRs can be detected by standard PCR methods and can be transferable to related taxa (Chen et al., 2015). The chloroplast genome is widely used in plant taxonomic and systematic studies (Rajendrakumar et al., 2007; Tambarussi et al., 2009) because it is usually maternally inherited and slowly evolving, and has a low frequency of genetic recombination (Birky and Walsh, 1988) but a high frequency of microsatellite repeats (Bryan et al., 1999; Provan et al., 1999). For these reasons, chloroplast markers are especially useful in genetic diversity and population genetic structure analyses, phylogenetic and phylogeographic analyses, and in hybrid identification of plants.

There are about 300 species in the genus Clematis L., which makes it the largest genus in Ranunculaceae (Grey, 2000; Wang and Li, 2005). The genus consists of typically vigorous, woody, climbing vines that are mainly distributed in the temperate zone of the northern hemisphere (Hao et al., 2013). The genus Clematis is famous for its diverse flower shapes and colors (Roh and Song, 1997); with the hundreds of cultivars, Clematis is known as the "Queen of the Vines". Clematis cultivars are also used for medicinal purposes because triterpenoid saponins, flavonoids, and many 
other compounds are present in various species (He et al., 2011).

Previous studies on the classification and phylogeny on Clematis were mainly based on morphological traits; phyllotaxy, sepals, cotyledon, and calyces have been used to characterize different species of Clematis (Goodley, 1977; Tobe et al., 1980; Keener and Dennis, 1982; Essig, 1991). More recently, different molecular marker systems have been applied to studies of Clematis. Inter-simple sequence repeat markers (ISSR) have been used to fingerprint 32 vining cultivars and five non-vining Clematis species to assess their genetic relationships and cultivar identification (Nicole and Stan, 2005). Random amplified polymorphic DNA (RAPD) has been used to confirm Clematis hybrids (Tao et al., 2010), and sequences of chloroplast DNA such as the $a t p B-r b c L$ spacer region, $m a t K, \operatorname{trn} K$, trnL intron, and $\operatorname{trn} L$-trnF spacer region, as well as the nuclear actin I intron have been used for the analysis of phylogenetic relationships within the Clematis genus (Johansson and Jansen, 1993; Johansson, 1995; Miikeda et al., 1999, 2006; Slomba et al., 2004; Shuang et al., 2016). Internal transcribed spacer (ITS) sequences have been analyzed to provide molecular evidence for the current phylogeny of the genus, and also for the identification of medicinal Clematis species (Ming et al., 2011, Xie et al., 2011; Xiao et al., 2012).

Classifications based on morphology and molecular methods have produced diverging results. According to Osamu et al. (2006), the inconsistencies between previous classification systems and molecular analyses indicate that several characters, such as the presence of filament hairs and the position of the inflorescences on the shoot (upper or lower part of stems), are homoplasious and do not clarify the 
phylogenetic relationships. However, leaf margin characters, which had not been previously used to characterize Clematis, were found to be useful in defining subgenera (Osamu et al., 2006).

Currently, there is a lack of SSR or cpSSR markers capable of effectively detecting polymorphisms and confirming cultivar identity in Clematis. To improve precision in genetic analyses on Clematis, we developed cpSSR markers to investigate inter- and intraspecific diversity among Clematis samples. Such markers will also be useful tools when searching for cytoplasm donors to breed new ornamental cultivars. Additionally, we compared relationships among Clematis species based on two types of genetic tools: cpSSR markers developed in this study and the common "phylogeny tool" ITS sequencing, to test whether the results from both methods are congruent or not.

85

\section{Sampling and DNA extraction}

\section{Materials and Methods}

We analyzed 43 accessions that represent 11 Clematis species (Table 1) that were collected from the Zhejiang province of China. All vouchers are deposited at the Zhejiang A \& F University. Total genomic DNA was extracted from dry leaf tissue using the E.Z.N.A Plant DNA Mini Kit Spin Protocol (Omega Bio-tek, Inc.) according to the manufacturer's instructions. 


\section{Primer design}

The SSR locations were searched from the complete chloroplast genome of Clematis terniflora (GenBank, accession KM652489.1) using the SSRIT tool (http://archive.gramene.org/db/markers/ssrtool). Ten adequate SSR regions were identified using the following criteria: length (at least ten copies for mononucleotide repeats and at least six copies for other types of SSRs) of the repeat sequence and good flanking primer sites. Then, primer pairs were designed for these regions using Primer Premier 5.0

(http://downloads.fyxm.net/download-now-Primer-Premier-Others-Home-\&-Educatio n-101178.html) using following parameters: primer length of 20-25 bp, a PCR product size of $100-300 \mathrm{bp}$, annealing temperature between $50-65^{\circ} \mathrm{C}$, and a GC content of 30-60\% (Table 2). Primers used for ITS sequencing were ITS1 (5'-CTT GGT CAT TTA GAG GAA GTA A-3') and ITS4 (5'-TCC TCC GCT TAT TGA TAT GC-3') (Gardes and Bruns, 1993)

\section{PCR amplification and data analysis}

PCR reactions for the selected ten SSR regions were carried out in $20-\mu$ l volumes

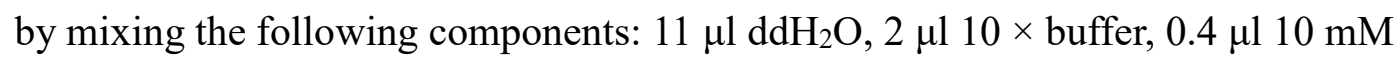
dNTPs, $0.6 \mu$ Dynazyme II DNA polymerase (Thermo Fisher Scientific, $2 \mathrm{U}_{\mu \mathrm{l}^{-1}}$ ), 2 $\mu \mathrm{l}$ genomic DNA (about $20 \mathrm{ng}$ ) and $2 \mu \mathrm{l}$ both primers $\left(5 \mathrm{pmol} \mu \mathrm{l}^{-1}\right)$. The forward primers were fluorescently labeled with FAM or HEX. The PCR reactions were 
carried out with an initial denaturation for $45 \mathrm{~s}$ at $94^{\circ} \mathrm{C}$, followed by 35 cycles of $30 \mathrm{~s}$ at $94^{\circ} \mathrm{C}, 30 \mathrm{~s}$ at the cpSSR-specific annealing temperature (Table 2), $40 \mathrm{~s}$ of elongation at $72^{\circ} \mathrm{C}$, and with a final elongation at $72^{\circ} \mathrm{C}$ for $5 \mathrm{~min}$. After amplification, the PCR products were diluted 1:20-1:200 depending on the concentration (the final concentration about $1 \mathrm{ng} \mu \mathrm{l}^{-1}$ ) with Milli-Q water. The DNA fragments were analyzed using a capillary electrophoresis system 3730 DNA Analyzer (Applied Biosystems). The DNA fragment sizes were determined using Peak Scanner ver. 2.0 (Applied Biosystems). The observed number of alleles $(\mathrm{Na})$, effective number of alleles $(\mathrm{Ne})$ and polymorphism information content (PIC) were estimated with PowerMarker V3.25 (Liu and Muse, 2005). Phylogenetic trees were constructed with PowerMarker V3.25 using the UPGMA method based on genetic distances described by Nei (1983). The PCR reactions preceding ITS sequencing were performed in a total volume

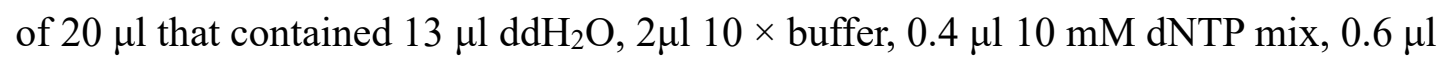

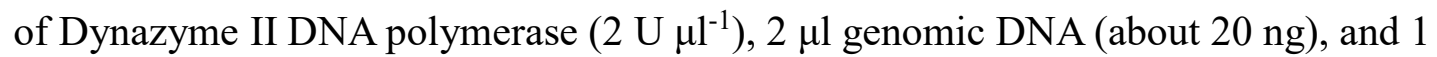
$\mu \mathrm{l}$ both primers $\left(5 \mathrm{pmol} \mu \mathrm{l}^{-1}\right)$. The PCR cycle was similar to that used for SSR genotyping, but the annealing temperature was $50^{\circ} \mathrm{C}$. Amplification products were run in a $1 \%$ agarose gel, and the DNA fragments were excised and purified prior to sequencing using the E.Z.N.A. Gel Extraction Kit (Omega Bio-Tek). Purified DNA samples were sequenced at Macrogen Inc. using the same primers utilized in the PCR reactions preceding ITS sequencing. The ITS sequences were manually checked using Chromas 2.5.0 (http://chromas.software.informer.com) and then aligned using Clustal X (http://www.clustal.org). The aligned data were analyzed using Mega 6.0 
(http://www.megasoftware.net) and genetic distances between species were determined using the Kimura-2 method (Kimura, 1980). Phylogenetic trees were drafted using the UPGMA method and the Kimura-2 parameter model in Mega 6.0.

\section{Results and Discussion}

\section{Development and assessment of cpSSR primers for identifying Clematis species}

Aside from DNA sequencing-based investigations, there are only a limited number of molecular marker studies of Clematis. These include the report of ISSR primers (Nicole and Stan 2005) and randomly amplified polymorphic DNA (RAPD; Tao et al., 2010); however, none of these previous investigations have utilized SSR markers. The present study developed cpSSR markers based on the available chloroplast genome of $C$. terniflora and successfully applied them to investigate intraand interspecific polymorphisms in Clematis. The polymorphic cpSSR markers can distinguish different species from each other and can be used in cultivar identification as well.

All ten cpSSR markers gave clear amplification products and seven were polymorphic within the genus (Table 3). A total of 28 alleles were discovered in the ten cpSSR loci among the 11 representative Clematis species. All amplified fragments were around the predicted sizes (Table 2, Table 4), indicating that the detected polymorphism mainly arose from variation in the number of cpSSR repeats. All 
markers amplified in all species, except for loci Clecp2 and Clecp7 in C. lasiandra, which was probably due to the failure of the primers to anneal at those locations. The allele numbers per locus ranged from one to seven within the genus (Table 3 ). The average number of alleles $(\mathrm{Na})$, effective number of alleles $(\mathrm{Ne})$, and polymorphism information content (PIC) were 2.8, 1.9, and 0.29, respectively, for the whole dataset (Table 3). In previous cpSSR-based studies, the mean PIC values equaled 0.19 in common bean cultivars (Ceylan et al., 2014), 0.21 in cowpea (Pan et al., 2014), 0.32 in Gladiolus cultivars (Singh et al., 2017) and 0.60 in cotton (Li et al., 2014). These examples show that PIC values of cpSSR markers can vary considerably and that the value detected in this study falls within the observed range of variation.

The UPGMA dendrogram was constructed using all cpSSR allele information and samples from the same species clearly grouped together (Figure 1). Five main clusters were generated: C. lasiandra $(37,38)$, C. patens subsp. tientaiensis (41), and $C$. henryi (27-30) grouped in clusters I, II, and III, respectively. C. terniflora (40), C. chinensis var. anhweiensis (42), C. courtoisii $(43)$, and C. hancockiana $(35,36)$ were closely connected in the dendrogram and grouped with $C$. apiifolia (1-14) to form cluster IV. C. brevicaudata (31-34), C. finetiana (15-26), and C. uncinata (39) grouped as a cluster V.

\section{ITS sequencing}

The sequenced ITS region covered the whole distance from the end of the $18 \mathrm{~S}$ rRNA gene to the beginning of the 26S rRNA gene (GenBank accession numbers 
KY201178- KY201188). The length of the entire ITS region (ITS1+5.8S+ITS2) from the 11 Clematis species varied between $534-562 \mathrm{bp}$. The ITS1 and ITS2 regions varied from 156-180 and 218-224 bp, respectively. C. courtoisii and C. hancockiana had the longest and $C$. henryi the shortest ITS regions. Among all species, the length of the 5.8S rRNA varied between $158-159 \mathrm{bp}$. The average GC content was $61.6 \%$ for the entire ITS region, $60.3 \%$ for ITS1, $68.5 \%$ for ITS2, and $53.2 \%$ for the $5.8 \mathrm{~S}$ rRNA region (Table 5). Thus, some length variation was detected for the ITS regions among the Clematis species.

The numbers of variable sites and parsimony-informative sites within the ITS region equaled 79 and 38 , and accounted for $13.8 \%$ and $6.6 \%$,of the sites within the entire ITS region, respectively. The numbers of variable sites and parsimony-informative sites within ITS1, ITS2, and 5.8S rRNA regions were 39, 33, 7, and 24, 11, 3, respectively. Thus, variation was abundant and included both SNPs and indels. The studied species were characterized by considerable divergence, with genetic distances varying between 0.008-0.073 (Table 6). The smallest distance was 0.008, which was found between C. hancockiana and C. patens subsp. tientaiensis, while $C$. finetiana and $C$. courtoisii were the most divergent species with a distance value of 0.073 . The average pairwise genetic distance equaled 0.039 . When a dendrogram was constructed for the 11 Clematis species using the UPGMA method, we discovered four clusters (Figure 2). The first cluster (I) was composed of C. lasiandra, C. apiifolia, C. henryi, C. brevicaudata, and C. uncinata. C. chinensis var. anhweiensis; C. terniflora were grouped in cluster II; C. courtoisii, $C$. 
hancockiana, and C. patens subsp. tientaiensis were grouped in cluster III; and C.

finetiana was separated from the other species in cluster IV. These sequencing results correspond previous analyses quite well (Ming et al., 2011; Xie et al., 2011).

\section{Molecular markers as characterization and phylogenetic tools}

It is widely recognized that the traditional use of morphological traits for taxon identification has several limitations, which include the misidentification of a taxon due to the phenotypic plasticity of the traits studied, the existence of cryptic taxa or the applicability of certain morphological keys only for a particular life stage (Valentini et al., 2009). In Clematis, the presence of filament hairs and the position of the inflorescences on the shoot (upper or lower part of stems) are homoplasious and do not inform phylogenetic relationships (Osamu et al., 2006). It is worth noting that convergent evolution may also confuse the interpretation of morphological traits; for instance, in the family Brassicaceae, there has been prevalent convergent evolution of several traits through time (Huang et al., 2016).

The species C. lasiandra, C. apiifolia, C. henryi, and C. brevicaudata included in our study share a common character of serrate leaf margins, which is supposed to be an indication of a close evolutionary relationship. Also, their pairwise genetic distances based on ITS sequences were quite small (0.010-0.022). The character state of entire leaf margins is shared by the other seven investigated Clematis species and therefore, the ITS-based relationships were found to correspond morphologically. For the most part, our results on Clematis relationships based on ITS regions agreed with 
the ITS sequence analyses presented by Ming et al. (2011) and Xie et al. (2011), which were based on nuclear ITS and plastid data.

In the cpSSR-derived tree, the seven species with entire leaf margins were sorted into three clades: $C$. terniflora, $C$. chinensis var. anhweiensis, $C$. courtoisii and $C$. hancockiana clustered together in the subgroup of clade IV; C. uncinata and $C$. finetiana were in the same subgroup of clade $\mathrm{V}$; and C. patens subsp. tientaiensis formed clade II. Among them, C. chinensis var. anhweiensis and C. terniflora had a close relationship based on both cpSSR and ITS data. Also, C. courtoisii and $C$. hancockiana belonged to the same group in both UPGMA trees. However, the grouping schemes of the other seven species were quite different in cpSSR-and ITS-based trees. For example, C. lasiandra and C. apifolia belonged to two separate clusters in the cpSSR tree, while they were grouped into the same cluster in the ITS-based tree. Thus, the trees produced with cpSSR markers and ITS sequences did not correspond with each other, possibly because of lineage sorting or introgression (Wendel and Doyle, 1998), the relatively narrow range of markers and sequences used in this study, or the size homoplasy for cpSSR markers, which may limit the phylogenetic power of cpSSRs (Wheeler et al., 2014). The main strength of SSRs and comparable markers is rather in species and genotype identification instead of revealing phylogenetic relationships.

To the best of our knowledge, this is the first report on the development and use of any kind SSR markers in the genus Clematis. These markers can be used in further studies on genetic diversity, population genetics and phylogeography of Clematis, as 
well as assist in the breeding of new ornamental cultivars.

Acknowledgments: This work was supported by the Nikolai and Ljudmila

Borisoff Foundation and the Fund of Forestry Key Disciplines of ZheJiang Province

(China).

\section{Literature Cited}

Birky CW Jr, Walsh JB (1988) Effects of linkage on rates of molecular evolution. Proc Natl Acad Sci USA 85:6414-6418

Bryan GJ, Mcbicoll J, Ramsay G, Meyer RC, De Jong WS (1999) Polymorphic simple sequence repeat markers in chloroplast genomes of Solanaceous plants. Theor Appl Gen 99:859-867

Ceylan A, Öcal, N, MikailAkbulut $M$ (2014) Genetic diversity among the Turkish common bean cultivars (Phaseolus vulgaris L.) as assessed by SRAP, POGP and cpSSR markers. Biochem Syst Ecol 54:219-229

Chen H, Liu L, Wang L, Wang S, Somta P, Cheng X (2015) Development and validation of EST-SSR markers from the transcriptome of adzuki bean (Vigna angularis). PLOS One 10:1-14

Essig FB (1991) Seedling morphology in Clematis (Ranunculaceae) and its taxonomic implications. Sida 14:377-390 
Gardes M, Bruns TD (1993) ITS primers with enhanced specificity for basidiomycetes-application to the identification of mycorrhizae and rusts. Mol Ecol 2:113-118

Goodley EJ (1977) Imbricate sepals in Clematis. N Zeal J Bot 15:775-776

Hao DC, Gu XJ, Xiao PG, Peng Y (2013) Chemical and biological research of Clematis medicinal resources. Chin Sci Bull 58:1120-1129

He YX, Li L, Zhang K, Liu ZR (2011) Cytotoxic triterpene saponins from Clematis mandshurica. J Asian Nat Prod Res 13:1104-1109

Huang C-H, Sun R, Hu Y, Zeng L, Zhang N, Cai L, Zhang Q, Koch MA, Al-Shehbaz I, Edger PP, J. Pires JC, Tan D-Y, Zhong Y, Ma H (2016) Resolution of Brassicaceae phylogeny using nuclear genes uncovers nested radiations and supports convergent morphological evolution. Mol Biol Evol $33: 394-412$

Johansson JT, Jansen RK (1993) Chloroplast DNA variation and phylogeny of the Ranunculaceae. Plant Syst Evol 187:29-49

Johansson JT (1995) A revised chloroplast DNA phylogeny of the Ranunculaceae. Plant Syst Evol 9 (Suppl.):253-262

Keener CS, Dennis WM (1982) The subgeneric classification of Clematis (Ranunculaceae) in temperate North America north of Mexico. Taxon 31:37-44

Kimura M (1980) A simple method for estimating evolutionary rate base substitution comparative studies nucleotide sequences. J Mol Evol 16:111-120

Li P, Li Z, Liu H, Hua J (2014) Cytoplasmic diversity of the cotton genus as 
revealed by chloroplast microsatellite markers. Genet Resour Crop Evol $61: 107-119$

Litt M, Luty JA (1989) A hypervariable microsatellite revealed by in vitro amplification of a dinucleotide repeat within the cardiac muscle actin gene. Am J Hum Gen 44:397-401

Liu K, Muse SV (2005) PowerMarker: an integrated analysis environment for genetic marker analysis. Bioinformatics 21:2128-2129

Miikeda O, Kita K, Handa T, Yukawa T (2006) Phylogenetic relationships of Clematis (Ranunculaceae) based on chloroplast and nuclear DNA sequences. Bot J Linn Soc 152:153-168

Miikeda O, Koga S, Handa T, Yukawa T (1999) Subgeneric relationships in Clematis (Ranunculaceae) by DNA sequences. In S Andrews, A Leslie, C Alexander, eds, Taxonomy of Cultivated Plants. Third International Symposium. Royal Botanic Gardens, London, UK, pp. 355-358

Ming J, Qiao ZY, Rong RL (2011) ITS sequence analysis of eight medicinal plants in Clematis L. Chin Trad Herb Drugs 42:1802-1806

Morgante M, Hanafey M, Powell W (2002) Microsatellites are preferentially associated with nonrepetitive DNA in plant genomes. Nature Gen 30:94-200

Nicole G, Stan CH (2005) Intersimple sequence repeat fingerprinting and genetic variation in a collection of Clematis cultivars and commercial germplasm. Hortic Sci 40:1982-1987

Pan L, Li Y, Guo R, Wu H, Hu Z, Chen C (2014) Development of 12 chloroplast 
microsatellite markers in Vigna unguiculata (Fabaceae) and amplification in Phaseolus vulgaris. Appl Plant Sci 2: 1300075. DOI: 10.3732/apps.1300075

Provan J, Soranzo N, Wilson NJ, Goldetein DB, Powell W (1999) A low mutation rate for chloroplast microsatellites. Genetics 153:943-947

\section{Rajendrakumar P, Biswal AK, Balachandran SM, Srinivasarao K, Sundaram} RM (2007) Simple sequence repeats in organellar genomes of rice: frequency and distribution in genic and intergenic regions. Bioinformatics 23:1-4

Roh MD, Song CY (1997) Effect of temperature and photoperiod on growth and flowering of potted dwarf Clematis. Korean Soc Hort Sci 38:429-434

Selkoe KA, Toonen RJ (2006) Microsatellites for ecologists: a practical guide to using and evaluating microsatellite markers. Ecol Lett 9:615-629

Shuang XY, Hui JL, Le LL, Shuai L, Jin YL, Lin YP, Lei X (2016) Taxonomic status of Clematis acerifolia var. elobata, based on molecular evidence. Phytotaxa 268:209-219

Singh N, Pal AK, Roy RK, Tamta S, Rana TS (2017) Development of cpSSR markers for analysis of genetic diversity in Gladiolus cultivars. Plant Gene $10: 31-36$

Slomba JM, Garey JR, Essig FB (2004) The actin I intron-a phylogenetically informative DNA region in Clematis (Ranunculaceae). SIDA 21:879-886

Tambarussi EV, Melotto-Passarin DM, Gonzalez SG, Brigati JB, de Jesus FA, Barbosa AL, Dressano K, Carrer H (2009) In silico analysis of simple sequence repeats from chloroplast genomes of Solanaceae species. Crop Breed 
338 Tao Y, Yin WL, Mark SR (2010) Confirmation of Clematis hybrids using 339 molecular markers. Sci Hort 125:136-145

340 Tobe H (1980) Morphological studies on the genus Clematis Linn., VII.

341 Reinvestigation of Clematis williamsii A. Gray and proposal of its taxonomic

342 transfer to Clematopsis. Bot Mag, Tokyo 93:135-148

343 Valentini A, Pompanon F, Taberlet P (2009) DNA barcoding for ecologists. Trends 344 in Ecol Evol 24:110-117

345 Wang WT, Li LQ (2005) A new system of classification of the genus Clematis 346 (Ranunculaceae). Acta Phytotax Sin 43:431-488

347 Wendel JF, Doyle JJ (1998) Phylogenetic incongruence: window into genome 348 history and molecular evolution. In D Soltis, P Soltis, J Doyle, eds, Molecular 349 Systematics of Plants, 2nd edn. Chapman and Hall, New York, pp. 265-296

350 Xiao L, Pei W, Long Z, Hua AJ (2012) rDNA-ITS sequence analysis of the 351 traditional mongolian medicinal plants in Clematis L. Acta Acad Med Neimongol $34: 325-330$

Xie L, Wen J, Li LQ (2011) Phylogenetic analyses of Clematis (Ranunculaceae) Based on sequences of nuclear ribosomal ITS and three plastid regions. Syst Bot 36:907-921 
Table 1. Information of the Clematis samples used for cpSSR and ITS analyses

\begin{tabular}{|c|c|c|c|c|c|}
\hline Number & Taxon & Origin & Coordinates & Sample size & Altitude (m) \\
\hline 1 & C. finetiana & Tian mu mountain (Lin an) & $30^{\circ} 15^{\prime} 37.56^{\prime \prime} \mathrm{N}, 119^{\circ} 16^{\prime} 57.92^{\prime \prime} \mathrm{E}$ & 3 & $499-589$ \\
\hline 2 & C. finetiana & & & & \\
\hline 3 & C. finetiana & & & & \\
\hline 4 & C. finetiana & Wu li village (Lin an) & $30^{\circ} 19^{\prime} 36.66^{\prime \prime} \mathrm{N}, 119^{\circ} 15^{\prime} 24.72^{\prime \prime} \mathrm{E}$ & 5 & $399-500$ \\
\hline 5 & C. finetiana & & & & \\
\hline 6 & C. finetiana & & & & \\
\hline 7 & C. finetiana & & & & \\
\hline 8 & C. finetiana & & & & \\
\hline 9 & C. finetiana & Ling long mountain (Lin an) & $30^{\circ} 13^{\prime} 03.61^{\prime \prime} \mathrm{N}, 119^{\circ} 40^{\prime} 02.67^{\prime \prime} \mathrm{E}$ & 6 & $111-144$ \\
\hline 10 & C. finetiana & & & & \\
\hline 11 & C. finetiana & & & & \\
\hline 12 & C. finetiana & & & & \\
\hline 13 & C. finetiana & & & & \\
\hline 14 & C. finetiana & & & & \\
\hline 15 & C. apiifolia & Tian mu mountain (Lin an) & $30^{\circ} 10^{\prime} 02.33^{\prime \prime} \mathrm{N}, 119^{\circ} 01^{\prime} 44.13^{\prime \prime} \mathrm{E}$ & 9 & $533-610$ \\
\hline 16 & C. apiifolia & & & & \\
\hline 17 & C. apiifolia & & & & \\
\hline 18 & C. apiifolia & & & & \\
\hline 19 & C. apiifolia & & & & \\
\hline 20 & C. apiifolia & & & & \\
\hline 21 & C. apiifolia & & & & \\
\hline 22 & C. apiifolia & & & & \\
\hline 23 & C. apiifolia & & & & \\
\hline 24 & C. apiifolia & Ban shan village (Lin an) & $30^{\circ} 14^{\prime} 35.82^{\prime \prime} \mathrm{N}, 119^{\circ} 14^{\prime} 14.44^{\prime \prime} \mathrm{E}$ & 3 & $553-661$ \\
\hline 25 & C. apiifolia & & & & \\
\hline 26 & C. apiifolia & & & & \\
\hline
\end{tabular}




\begin{tabular}{|c|c|c|c|c|c|}
\hline 27 & C. henryi & Sankou mountain (Anji county) & $30^{\circ} 24^{\prime} 30.05^{\prime \prime} \mathrm{N}, 119^{\circ} 40^{\prime} 35.96^{\prime \prime} \mathrm{E}$ & 4 & $670-733$ \\
\hline 28 & C. henryi & & & & \\
\hline 29 & C. henryi & & & & \\
\hline 30 & C. henryi & & & & \\
\hline 31 & C. brevicaudata & Longgang village (Shaoxing county) & $29^{\circ} 50^{\prime} 17.47^{\prime}{ }^{\prime} \mathrm{N}, 120^{\circ} 39^{\prime} 26.93^{\prime \prime} \mathrm{E}$ & 4 & 431 \\
\hline 32 & C. brevicaudata & & & & \\
\hline 33 & C. brevicaudata & & & & \\
\hline 34 & C. brevicaudata & & & & \\
\hline 35 & C. hancockiana & Qianqiu mountain (Lin an) & $30^{\circ} 19^{\prime} 54.09^{\prime} \mathrm{N}, 119^{\circ} 16^{\prime} 02.61^{\prime \prime} \mathrm{E}$ & 2 & $579-597$ \\
\hline 36 & C. hancockiana & & & & \\
\hline 37 & C. lasiandra & Wu li village (Lin an) & $30^{\circ} 16^{\prime} 27.88^{\prime \prime} \mathrm{N}, 119^{\circ} 06^{\prime} 16.28^{\prime \prime} \mathrm{E}$ & 2 & 503 \\
\hline 38 & C. lasiandra & & & & \\
\hline 39 & C. uncinata & Wu li village (Lin an) & $30^{\circ} 16^{\prime} 27.88^{\prime \prime} \mathrm{N}, 119^{\circ} 06^{\prime} 16.28^{\prime \prime} \mathrm{E}$ & 1 & 503 \\
\hline 40 & C. terniflora & Ling long mountain (Lin an) & $30^{\circ} 13^{\prime} 18.21^{\prime \prime} \mathrm{N}, 119^{\circ} 40^{\prime} 06.62^{\prime \prime} \mathrm{E}$ & 1 & 97 \\
\hline 41 & $\begin{array}{l}\text { C. patens subsp. } \\
\text { tientaiensis }\end{array}$ & Nan shan village (Tian tai county) & $29^{\circ} 07^{\prime} 56.05^{\prime}{ }^{\prime} \mathrm{N}, 121^{\circ} 19^{\prime} 18.44^{\prime \prime} \mathrm{E}$ & 1 & 735 \\
\hline 42 & $\begin{array}{l}\text { C. chinensis var. } \\
\text { anhweiensis }\end{array}$ & Liu an city anhui province & $31^{\circ} 05^{\prime} 52.80^{\prime \prime} \mathrm{N}, 115^{\circ} 44^{\prime} 54.49^{\prime \prime} \mathrm{E}$ & 1 & 791 \\
\hline 43 & C. courtoisii & Tian mu mountain (Lin an) & 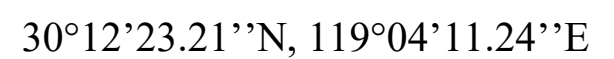 & 1 & 477 \\
\hline
\end{tabular}


Table 2. Ten cpSSR primer pairs developed for Clematis used in this study

\begin{tabular}{|c|c|c|c|c|}
\hline Locus & Repeat type & Primer sequence ( $5^{\prime}$ to $\left.3^{\prime}\right)$ & $\begin{array}{l}\mathrm{TM} \\
\left({ }^{\circ} \mathrm{C}\right)\end{array}$ & Product size (bp) \\
\hline \multirow{2}{*}{ Clecp1 } & \multirow{2}{*}[\mathrm{T}/\mathrm{A}]{$_{19}$} & F: TTTGTTCATGCGGTACTCCTTT & \multirow{2}{*}{59} & \multirow{2}{*}{138} \\
\hline & & R: ATCTTGTCTATTCCCACGGTTC & & \\
\hline \multirow{2}{*}{ Clecp2 } & \multirow{2}{*}[\mathrm{T}]{$_{14}$} & F: AAGATACCGCTGTGCCAGGATA & \multirow{2}{*}{61} & \multirow{2}{*}{125} \\
\hline & & R: AGAAGCCGAGTAAGCGGATTGG & & \\
\hline \multirow{2}{*}{ Clecp3 } & \multirow{2}{*}[\mathrm{A}/\mathrm{T}]{$_{16}$} & F: ATTTTCTATAACCTACCGTCTT & \multirow{2}{*}{50} & \multirow{2}{*}{116} \\
\hline & & R: TTGACTTCTACTATTTTGGTTG & & \\
\hline \multirow{2}{*}{ Clecp4 } & \multirow{2}{*}[\mathrm{A}]{$_{12}$} & F: GATAGGGGTCAATAAAAGAAAA & \multirow{2}{*}{53} & \multirow{2}{*}{111} \\
\hline & & R: ATAGGTGCATACAGTAGGCTCA & & \\
\hline \multirow{2}{*}{ Clecp5 } & \multirow{2}{*}[\mathrm{A}/\mathrm{T}]{$_{29}$} & F: TTGTTTTCCACATCGTGATTTC & \multirow{2}{*}{60} & \multirow{2}{*}{195} \\
\hline & & R: TGTCCACTCACTTTATTTTCTGAAC & & \\
\hline \multirow{2}{*}{ Clecp6 } & \multirow{2}{*}[\mathrm{A}/\mathrm{T}]{$_{36}$} & F: ATGGGGAGATAAAGAAATAGAG & \multirow{2}{*}{52} & \multirow{2}{*}{152} \\
\hline & & R: TACCAAAATAGGATGAAATAGG & & \\
\hline \multirow{2}{*}{ Clecp7 } & \multirow{2}{*}[\mathrm{G}/\mathrm{A}]{$_{22}$} & F: ACCAGTTGTTGCTGATACCTCCTT & \multirow{2}{*}{61} & \multirow{2}{*}{128} \\
\hline & & R: CGGTCGTTGTGGTCGGACTCTA & & \\
\hline \multirow{2}{*}{ Clecp8 } & \multirow{2}{*}[\mathrm{A}/\mathrm{T}]{$_{21}$} & F: AATGAAAGGGATGTTGAAAGAG & \multirow{2}{*}{567} & \multirow{2}{*}{170} \\
\hline & & R: CTGTCACGTACACGTAGGAATA & & \\
\hline \multirow{2}{*}{ Clecp9 } & \multirow{2}{*}[\mathrm{T}/\mathrm{C}]{$_{20}$} & F: TAGGGATATGGAACGAAAGGAA & \multirow{2}{*}{60} & \multirow{2}{*}{204} \\
\hline & & R: ATTAATTCTCTAGCCCCGCTGT & & \\
\hline Clecp 10 & {$[\mathrm{~T} / \mathrm{A}]_{30}$} & F: TCTATGAAATGCCAATCCAACA & 56 & 209 \\
\hline слесрі0 & {$[1 / A] 30$} & R: AAAAACTTATAGGGCGTGGATAAA & 50 & 209 \\
\hline
\end{tabular}


Table 3. Summary of genetic variation statistics for each cpSSR locus among all Clematis samples

\begin{tabular}{ccccc}
\hline Locus & Samples & $\mathrm{Na}$ & $\mathrm{Ne}$ & $\mathrm{PIC}$ \\
\hline Clecp1 & 43 & 7 & 3.23 & 0.65 \\
Clecp2 & 43 & 1 & 1.00 & 0.00 \\
Clecp3 & 43 & 1 & 1.00 & 0.00 \\
Clecp4 & 43 & 4 & 2.88 & 0.59 \\
Clecp5 & 43 & 2 & 1.05 & 0.04 \\
Clecp6 & 43 & 2 & 1.37 & 0.24 \\
Clecp7 & 43 & 3 & 1.00 & 0.00 \\
Clecp8 & 43 & 2 & 1.62 & 0.35 \\
Clecp9 & 43 & 5 & 3.74 & 0.37 \\
Clecp10 & 43 & 2.8 & 1.9 & 0.68 \\
Mean & & & & 0.29 \\
\hline
\end{tabular}

$\mathrm{Na}$, the observed number of alleles; Ne, effective number of alleles; PIC, polymorphism information content 
Table 4. Detected allele sizes of $10 \mathrm{cpSSR}$ loci in different Clematis species

\begin{tabular}{|c|c|c|c|c|c|c|c|c|c|c|c|}
\hline Locus & $\begin{array}{c}C . \\
\text { finetiana }\end{array}$ & C. apiifolia & C. henryi & $\begin{array}{c}C . \\
\text { brevicaudata }\end{array}$ & $\begin{array}{c}\text { C. } \\
\text { hancockiana }\end{array}$ & $\begin{array}{c}\text { C. } \\
\text { lasiandra }\end{array}$ & C. uncinata & $\begin{array}{c}C . \\
\text { terniflora }\end{array}$ & $\begin{array}{c}\text { C.patens } \\
\text { subsp. } \\
\text { tientaiensis } \\
\end{array}$ & $\begin{array}{c}\text { Clematis } \\
\text { chinensis var. } \\
\text { anhweiensis }\end{array}$ & $\begin{array}{c}\text { C. } \\
\text { courtoisit }\end{array}$ \\
\hline Clecp1 & 140,141 & 135 & $133,136,137$ & 135 & 127 & 135 & 133 & 135 & 127 & 135 & 127 \\
\hline Clecp2 & 122 & 122 & 122 & 122 & 122 & - & 122 & 122 & 122 & 122 & 122 \\
\hline Clecp3 & 112 & 112 & 112 & 112 & 112 & 112 & 112 & 112 & 112 & 112 & 112 \\
\hline Clecp4 & 108 & 106 & 105,106 & 107 & 106 & 105 & 106 & 106 & 106 & 106 & 107 \\
\hline Clecp5 & 193 & 193 & 193 & 193 & 193,194 & 193 & 193 & 193 & 193 & 193 & 193 \\
\hline Clecp6 & 149 & 149 & 149 & 150 & 149 & 150 & 149 & 149 & 150 & 149 & 149 \\
\hline Clecp7 & 124 & 124 & 124 & 124 & 124 & - & 124 & 124 & 124 & 124 & 124 \\
\hline Clecp8 & 168,169 & 168 & 173 & 168 & 168 & 169 & 169 & 168 & 169 & 168 & 168 \\
\hline Clecp9 & 204 & 203 & 203,204 & 203,204 & 204 & 204 & 203 & 204 & 204 & 204 & 204 \\
\hline Clecp10 & 231,232 & $229,230,231$ & 232 & 229,230 & 232 & 230 & 231 & 232 & 237 & 232 & 232 \\
\hline
\end{tabular}

-, no amplification 
Table 5. GenBank accession numbers, length (bp), and GC content (\%) of ITS sequences in 11 Clematis species

\begin{tabular}{|c|c|c|c|c|c|c|c|c|c|}
\hline \multirow{2}{*}{ Accession number } & \multirow{2}{*}{ Species } & \multicolumn{2}{|c|}{ ITS region } & \multicolumn{2}{|c|}{ ITS1 } & \multicolumn{2}{|r|}{ ITS2 } & \multicolumn{2}{|r|}{$5.8 \mathrm{~S}$} \\
\hline & & length & GC content & length & GC content & length & GC content & length & GC content \\
\hline KY201178 & $\begin{array}{l}\text { C. chinensis var. } \\
\text { anhweiensis }\end{array}$ & 549 & 62.1 & 169 & 59.8 & 221 & 70.6 & 159 & 52.8 \\
\hline KY201179 & C. apiifolia & 552 & 61.4 & 173 & 60.1 & 220 & 68.2 & 159 & 53.5 \\
\hline KY201180 & C. brevicaudata & 543 & 61.3 & 164 & 59.2 & 220 & 68.6 & 159 & 53.5 \\
\hline KY201181 & C. courtoisii & 562 & 63.2 & 180 & 63.9 & 220 & 68.6 & 158 & 54.4 \\
\hline KY201182 & C. finetiana & 543 & 59.3 & 166 & 58.4 & 218 & 67.0 & 159 & 49.7 \\
\hline KY201183 & C. hancockiana & 562 & 63.4 & 180 & 63.9 & 224 & 69.2 & 158 & 54.4 \\
\hline KY201184 & C. henryi & 534 & 60.1 & 156 & 57.7 & 219 & 67.1 & 159 & 52.8 \\
\hline KY201185 & C. lasiandra & 550 & 60.4 & 172 & 59.9 & 219 & 66.2 & 159 & 52.8 \\
\hline KY201186 & $\begin{array}{l}\text { C. patens subsp. } \\
\text { tientaiensis }\end{array}$ & 560 & 63.4 & 180 & 64.4 & 222 & 68.9 & 158 & 54.4 \\
\hline KY201187 & C. terniflora & 549 & 61.8 & 169 & 59.2 & 221 & 70.1 & 159 & 52.8 \\
\hline KY201188 & C. uncinata & 541 & 60.8 & 163 & 57.1 & 219 & 69.0 & 159 & 53.5 \\
\hline
\end{tabular}


Table 6. Pairwise divergence of Clematis species based on ITS sequences

\begin{tabular}{|c|c|c|c|c|c|c|c|c|c|c|c|c|}
\hline \multirow{2}{*}{\multicolumn{2}{|c|}{ Species }} & \multicolumn{11}{|c|}{ Genetic distance } \\
\hline & & 1 & 2 & 3 & 4 & 5 & 6 & 7 & 8 & 9 & 10 & 11 \\
\hline 1: & C. chinensis var. anhweiensis & - & & & & & & & & & & \\
\hline 2: & C. terniflora & 0.020 & - & & & & & & & & & \\
\hline 3: & C. brevicaudata & 0.032 & 0.036 & - & & & & & & & & \\
\hline 4: & C. henryi & 0.036 & 0.040 & 0.022 & - & & & & & & & \\
\hline 5: & C. lasiandra & 0.038 & 0.042 & 0.016 & 0.010 & - & & & & & & \\
\hline 6: & C. apiifolia & 0.038 & 0.044 & 0.014 & 0.016 & 0.010 & - & & & & & \\
\hline 7: & C. finetiana & 0.060 & 0.065 & 0.042 & 0.044 & 0.038 & 0.040 & - & & & & \\
\hline 8: & C. uncinata & 0.040 & 0.044 & 0.028 & 0.030 & 0.032 & 0.030 & 0.050 & - & & & \\
\hline 9: & C. courtoisii & 0.050 & 0.058 & 0.052 & 0.054 & 0.056 & 0.054 & 0.073 & 0.052 & - & & \\
\hline 10: & C. hancockiana & 0.038 & 0.046 & 0.040 & 0.042 & 0.044 & 0.042 & 0.060 & 0.040 & 0.012 & - & \\
\hline & C. patens subsp. tientaiensis & 0.036 & 0.044 & 0.036 & 0.038 & 0.040 & 0.038 & 0.056 & 0.038 & 0.020 & 0.008 & - \\
\hline
\end{tabular}

Kimura-2 parameter model was used to calculate genetic distances 


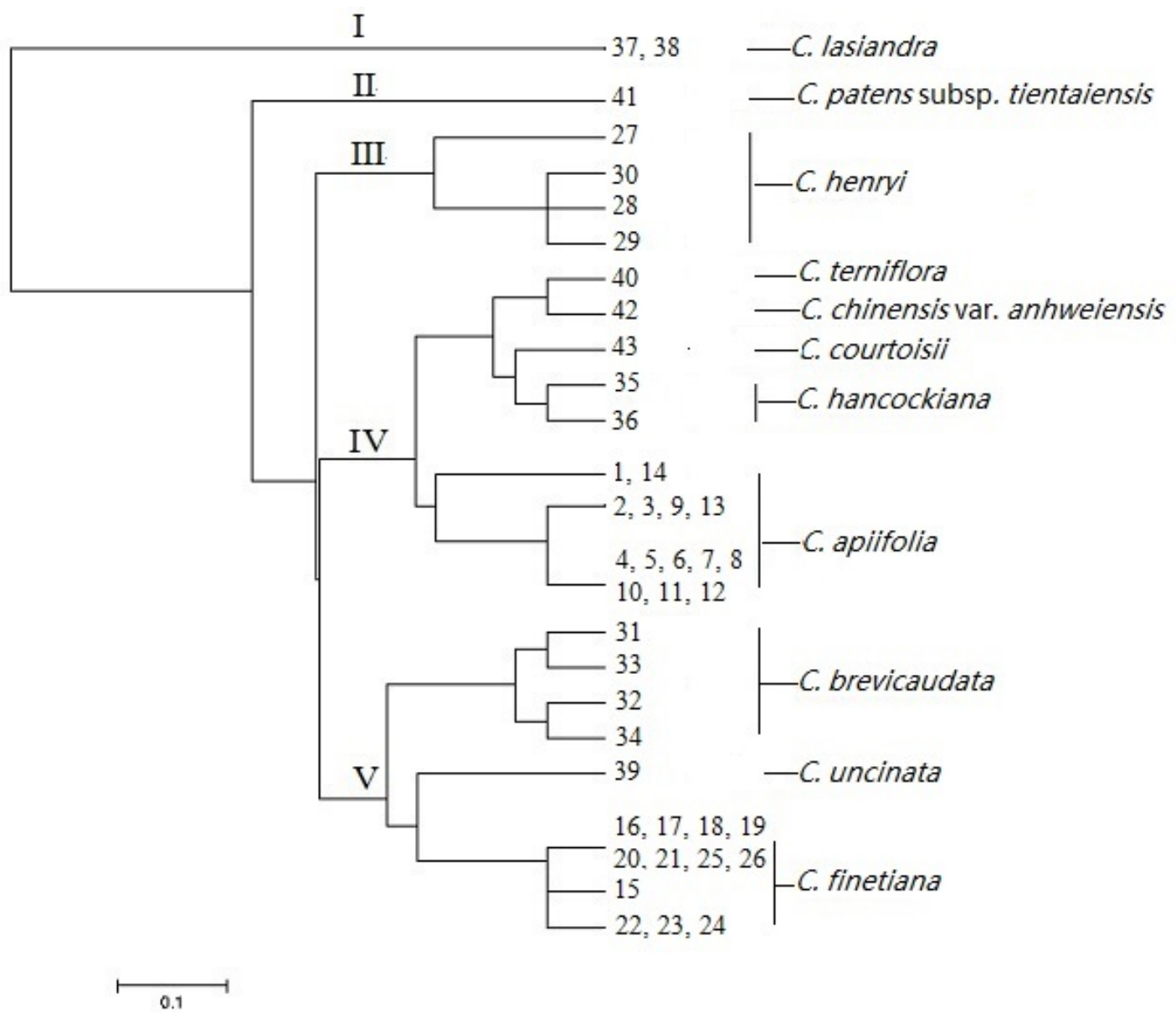

Fig. 1. A dendrogram of Clematis samples based on cpSSR variation. The sample numbers follow those in Table 1. The clusters are numbered from I to V. 


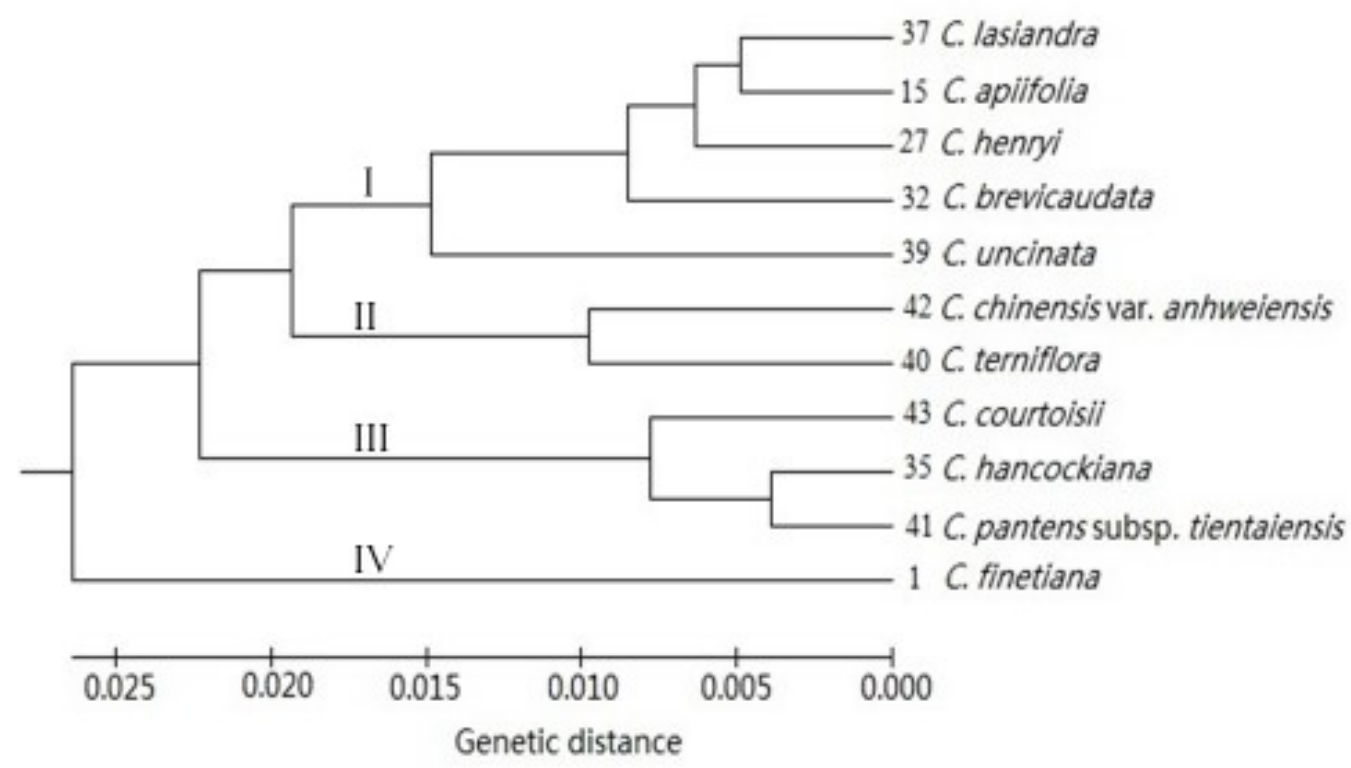

Fig. 2. A dendrogram of 11 Clematis species based on ITS sequence information. The sample numbers follow those in Table 1. The clusters are numbered from I to IV. 